\title{
Electrical Behaviour of Association Phenomena of Tetra aqua-1,10-phenanthroline Iron (II) Chloride in Methanol-Water Mixtures at Different Temperatures
}

\author{
Y.O. Hameed F.A. Thanon S.H. Abdul-Rahman \\ Chemistry Dept., College of Science, Mosul University
}

Received

$19 / 02 / 2007$
Accepted

15 / 08 / 2007

\section{الملغص}

مُ درلسة الخواص الكهربائية لمعقد الحديد ثنائي الليكند في نسب مختلفة مـ ن مـ خيب ثنائي من الميثانول والماء في درجلت حرارية مختلفة والتي تعطي معلوملت ء ـن ت د دلخلات اليون -ايون وايون -مذيب في المحلول. وقم حسلب كل من الدول الفيزياوية التالية (

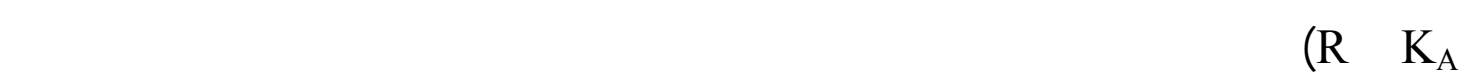

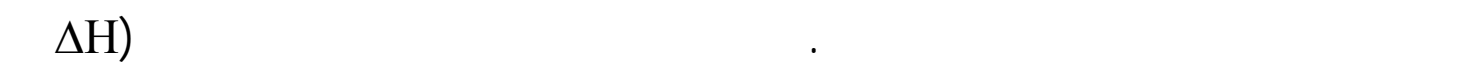

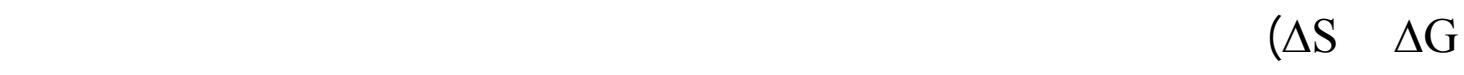

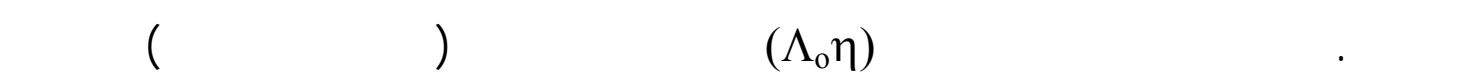
تعطي معلوملت عن كيفية التجمع الايوني في النهب المختلفة.

\begin{abstract}
The electrical behaviour of mixed ligand complex of $\mathrm{Fe}(\mathrm{II})$ in different percentage of binary mixture of methanol and water at different temperatures can give information about ion-ion and ion-solvent interaction in solution so the limiting molar conductance $\lambda_{\mathrm{Fe}^{2+}}^{\circ}, \mathrm{K}_{\mathrm{A}}$ the association constant and (R) the main distance between ions in solution as a results of those interaction can be calculated. Thermodynamics parameters $(\Delta \mathrm{H}, \Delta \mathrm{G}, \Delta \mathrm{S})$ of the association processes and the coulombic forces which play an important role in the association process also have been studied, Walden product also calculated for solvent composition which indicate the tendency of the association of the ions in different percentages.
\end{abstract}




\section{INTRODUCTION}

The conductivity measurements are useful as an effective means to understand the nature of solute-solvent interaction since the degree of ionic mobility is exceedingly sensitive to interactions. The characteristics of metal chelate electrolytes is of their solute-solvent interaction concerning charge, size and chemical properties of liquid have been elucidated by the study of the electronic spectra ${ }^{(1)}$ racemization $^{(2)}$, optical resolution $^{(3)}$, viscosity, molar volume ${ }^{(4)}$ and conductivity ${ }^{(5)}$. Very few work have been done on 1,10-phenanthroline and water as mixed ligand with any metal ion $^{(6)}$ had studied. The analytical applications of complexes of metal ions as $\mathrm{Mn}(\mathrm{II}), \mathrm{Ni}(\mathrm{II}), \mathrm{Co}(\mathrm{II})$ and $\mathrm{Cu}(\mathrm{II})$ with 1,10phenanthroline as ligand which have vary wide applications in industry and have a biological effects were studied by Lee-Wheaton equation to investigate their behaviour of interaction by conductivity ${ }^{(7)}$. Electrolytic conductivities of dilute solutions of $\mathrm{Ni}(\mathrm{II}), \mathrm{Cd}(\mathrm{II}), \mathrm{Mg}$ (II) and $\mathrm{Cu}(\mathrm{II})$ sulfate in binary mixture of methanol and water have been evaluated by using Lee-Wheaton equation ${ }^{(8)}$. The complexes have been screened against a number of fungi and bacteria to assess their growth inhibiting potential. In this work we have measured the electrical conductivities of [Fe(1,10-phenanthroline $\left.\left(\mathrm{H}_{2} \mathrm{O}\right)\right] \mathrm{Cl}_{2}$ in methanol water mixture at different temperatures $(288.15-308.15 \mathrm{~K})$ to investigate the thermodynamic behaviours by application of Lee-Wheaton equation and to elucidate the conductivity parameters of assymetrical electrolytes $2: 1\left(\lambda_{0}, K_{A}, R\right)$ in mixed solvents.

\section{EXPERIMENTAL}

Tetra aquo (1,10-phenanathroline) Iron (II) chloride was prepared by mixing $2 \mathrm{mM}$ of 1,10-phenanthroline in $10 \mathrm{~cm}^{3}$ of ethanol and $2 \mathrm{mM}$ of $\mathrm{FeCl}_{3} \cdot 4 \mathrm{H}_{2} \mathrm{O}$ in $30 \mathrm{~cm}^{3}$ of deionized water and refluxed for about $45 \mathrm{~min}$ on a water bath. On cooling and adding excess of absolute ethanol the complex was precipitated, filtered then washed with ice cold $50 \%$ ethanol and then recrystallized by slow cooling to $0{ }^{\circ} \mathrm{C}$ followed by addition of excess absolute ethanol ${ }^{(9)}$. The product was dried under vacuum over anhydrous calcium chloride. Electronic spectrum and infrared measurements are used for analysis of the complexes and also gas chromatography was used to determine water content and other organic impurities.

Methanol was purified and dried by the methanol described by Perrin $^{(10)}$. Conductivity water was prepared by distilling twice distilled water with specific conductance of $2 \times 10^{-6} \mu \mathrm{S}$. Conductivity measurements were made using Jenway PCM3 conductivity meter with frequency range of $50 \mathrm{~Hz}-1 \mathrm{KHz}$ and accuracy of $0.01 \mu \mathrm{S}$. The cell constant for the conductivity cell was measured using the method of 
Jones and Bradshaw ${ }^{(11)}, 0.01 \mathrm{M} \mathrm{KCl}$ solution was prepared from potassium chloride (BDH reagent) recrystallized three times from conductivity water and then dried at (760) Torr and $500{ }^{\circ} \mathrm{C}$ for $10 \mathrm{hrs}$. The cell constant was checked regularly and found to be $1.14 \mathrm{~cm}^{-1}$.

A general method has been used for measuring the conductance of the electrolytes. The conductivity cell was washed, dried and then weighed empty and kept at any temperature $\left( \pm 0.1^{\circ} \mathrm{C}\right)$ using a watercirculating ultra thermostat type VH5B radiometer. A certain amount of solution was injected into the conductivity cell and the conductivity of the solution was measured. Successive known amount of the solution was added and the measurement was repeated as before. Generally (14) additions have been made for any measurement.

\section{RESULTS AND DISCUSSION}

Lee-Wheaton equation is an extended form of the Debye-Hukel equation for the calculation of molar (or equivalent) conductance, association constant and main distance between ion in solution of electrolytes $^{(12)}$. Conductivity data were treated by this equation in which a wide temperature range for electrolyte solution can provide detailed information concerning ion-ion and ion-solvent interaction especially from thermodynamic point of view ${ }^{(13)}$.

For unsymmetrical electrolyte $\mathrm{MX}_{2}$ ionizing to $\mathrm{M}^{2+}$ and $\mathrm{X}^{-}$the possible equilibria are:

$$
\begin{array}{ll}
\mathrm{M}^{2+}+\mathrm{X}^{-} \stackrel{\mathrm{K}_{(1)}}{\rightleftharpoons} \mathrm{MX}^{+} \\
\mathrm{MX}^{+}+\mathrm{X}^{-} \stackrel{\mathrm{K}_{(2)}}{\rightleftharpoons} \mathrm{MX}_{2}
\end{array}
$$

Thus, three ionic species are present in the solution which are $\mathrm{M}^{2+}$, $\mathrm{MX}^{+}$and $\mathrm{X}^{-}$. All such solutions are in effect "mixed electrolyte" since the pair $\mathrm{MX}^{+}$is conducting species.

$\Lambda_{\text {equiv. }}=\sum_{\mathrm{i}=1}^{\mathrm{s}}\left|\mathrm{z}_{\mathrm{i}}\right| \mathrm{m}_{\mathrm{i}} \lambda_{\mathrm{i}} / \mathrm{C}$

This equation is derived as follows:

$$
\begin{aligned}
& \lambda_{\mathrm{i}}=f\left(\lambda_{\mathrm{i}}^{\circ}, \varepsilon \mathrm{K}, \mathrm{R}\right) \\
& \sigma_{\mathrm{i}}=\mathrm{C}_{\mathrm{i}} \lambda_{\mathrm{i}} / 1000=\left|\mathrm{z}_{\mathrm{i}}\right| \mathrm{m}_{\mathrm{i}} \lambda_{\mathrm{i}} / 1000 \\
& \text { and } \sigma_{\text {solu. }}=\sum_{\mathrm{i}=1}^{\mathrm{s}} \mid \mathrm{C}_{\mathrm{i}} \\
& \text { or } 1000 \sigma_{\text {solu. }}=\sum_{\mathrm{i}=1}^{\mathrm{s}} \mid \mathrm{C}_{\mathrm{i}} \lambda_{\mathrm{i}}
\end{aligned}
$$


and $\Lambda_{\text {solu. }}=\sum_{\mathrm{i}=1}^{\mathrm{s}}\left|\mathrm{z}_{\mathrm{i}}\right| \mathrm{m}_{\mathrm{i}} \lambda_{\mathrm{i}} / \sum \mathrm{C}_{\mathrm{i}}$

where (s) is the number of ionic species, $\sigma$ is specific conductance, $\mathrm{C}$ stoichiometric equivalent concentration, $\lambda_{\mathrm{i}}, \mathrm{m}_{\mathrm{i}}, \mathrm{C}_{\mathrm{i}}$ and $\mathrm{z}_{\mathrm{i}}$ are the equivalent conductance, molar free ion concentration, equivalent concentration and charge of the species respectively. The equation is:

$$
\begin{aligned}
& \lambda_{\mathrm{i}}=\lambda_{\mathrm{i}}^{\mathrm{o}}\left[1+\mathrm{z}_{\mathrm{j}} \sum_{\mathrm{p}=2}^{\mathrm{s}} \mathrm{z}_{\mathrm{i}} \mathrm{x}_{\mathrm{j}}^{\mathrm{p}} \sum_{\mathrm{v}=1}^{\mathrm{s}} \operatorname{tvx}_{\mathrm{v}}^{\mathrm{p}}\left(\mathrm{A}^{\mathrm{p}}(\mathrm{t})(\beta \mathrm{k})+\mathrm{B}_{\mathrm{v}}^{\mathrm{p}}(\mathrm{t})(\beta \mathrm{k})^{2}+\mathrm{C}_{\mathrm{v}}^{\mathrm{p}}(\mathrm{t})(\beta \mathrm{k})^{3}\right)\right] \\
& -\left[\frac{\mathrm{z}_{\mathrm{j}}(\mathrm{kt})}{2(1+\mathrm{t})}\left\{\mathrm{I}+\mathrm{v}_{\mathrm{j}}^{(1)}(\mathrm{t})(\beta \mathrm{k})+\mathrm{v}_{\mathrm{j}}^{(2)}(\mathrm{t})(\beta \mathrm{k})^{2}+\pi_{\mathrm{j}}^{(5)} \mathrm{t} / 6\right\}\right]
\end{aligned}
$$

$t$ is the transference number of species

$\beta=\mathrm{e}^{2} / \mathrm{DKT}, \mathrm{k}=4 \pi / \mathrm{DKT} \sum_{\mathrm{j}=1}^{\mathrm{s}} \mathrm{nje}_{\mathrm{j}}^{2}$ and is proportional to the strength, $\mathrm{t}=$

$\mathrm{KR}$ and $\mathrm{T}=\mathrm{Fe} / 6 \pi \eta, \mathrm{m}_{\mathrm{i}}$ is the molar free ion concentration of species I, $\mathrm{c}$ is the equivalent stoichiometric concentration of the electrolyte. The plasma coefficients $A_{v}^{p}, B_{v}^{p}$... etc are functions of $K R$ and $q_{p}$ (Bjeerum value) while the terms $X_{j}^{p}$ and $q_{p}$ are functions of the limiting mobilities. All other terms are defined in the original paper (Lee and Wheaton, $1978)^{(12)}$.

Thus for associated salts 2:1 unsymmetrical electrolyte:

$\Lambda \mathrm{M}^{2+}=f\left(\lambda_{\mathrm{M}^{2+}}^{\mathrm{o}}, \lambda_{\mathrm{MX}^{+}}^{\mathrm{o}}, \lambda_{\mathrm{X}^{-}}^{\mathrm{o}}, \mathrm{K}_{\mathrm{A}}^{(1)}, \mathrm{K}_{\mathrm{A}}^{(2)}, \mathrm{R}\right)$

where $\mathrm{R}$ is the average center to center distance for the ion pairs.

The input data to computer program are solvent data (Temp. T, dielectric constant $\mathrm{D}$, viscosity $\eta$ ), the charge and ionic mobility $\lambda^{\mathrm{o}}$ for each ionic species, $\mathrm{K}_{\mathrm{A}}^{(1)}, \mathrm{K}_{\mathrm{A}}^{(2)}, \lambda_{\mathrm{MX}^{+}}^{\mathrm{o}}, \lambda_{\mathrm{M}^{2+}}^{\mathrm{o}}$ and $\mathrm{R}$ all in the form $\mathrm{K}_{\mathrm{A}(\min )}^{(1)}$, $\mathrm{K}_{\mathrm{A}(\min )}^{(2)}, \Delta \mathrm{K}_{\mathrm{A}}^{(1)}$. . . . etc then the experimental data (molecular concentration and the equivalent conductances). This program is used to determine values of $\mathrm{K}_{\mathrm{A}}^{(1)}, \mathrm{K}_{\mathrm{A}}^{(2)}, \lambda_{\mathrm{MX}^{+}}^{\mathrm{o}}, \lambda_{\mathrm{M}^{2+}}^{\mathrm{o}}$ and $\mathrm{R}$ which minimize $\sigma_{\mathrm{s}}(\Lambda)$. Table (1A-D) show the molar concentration and equivalent conductance of $\left[\mathrm{Fe}(1,10-\mathrm{Phen})\left(\mathrm{H}_{2} \mathrm{O}\right)_{4}\right] \mathrm{Cl}_{2}$ in [50\%-90\%] methanol and water at different temperatures and Figure (1A-D) show the relation between them. It can be seen from Table (1A-D) that the equivalent conductance increase as temperature increase and decrease as methanol percent decrease because of increasing water percent and the formation of hydrogen bonds more and more except for $\% 50$ which increase due to the nutralinity between methanol and water and the increasing in dielectric constant of the mixed solvent at this percentage. 
The decrease of equivalent conductance with increasing concentration were shown in Figs. (1A-D) which obey Koloraush equation of weak electrolytes.

$\Lambda=\Lambda^{\circ}-\mathrm{aC}^{1 / 2}$

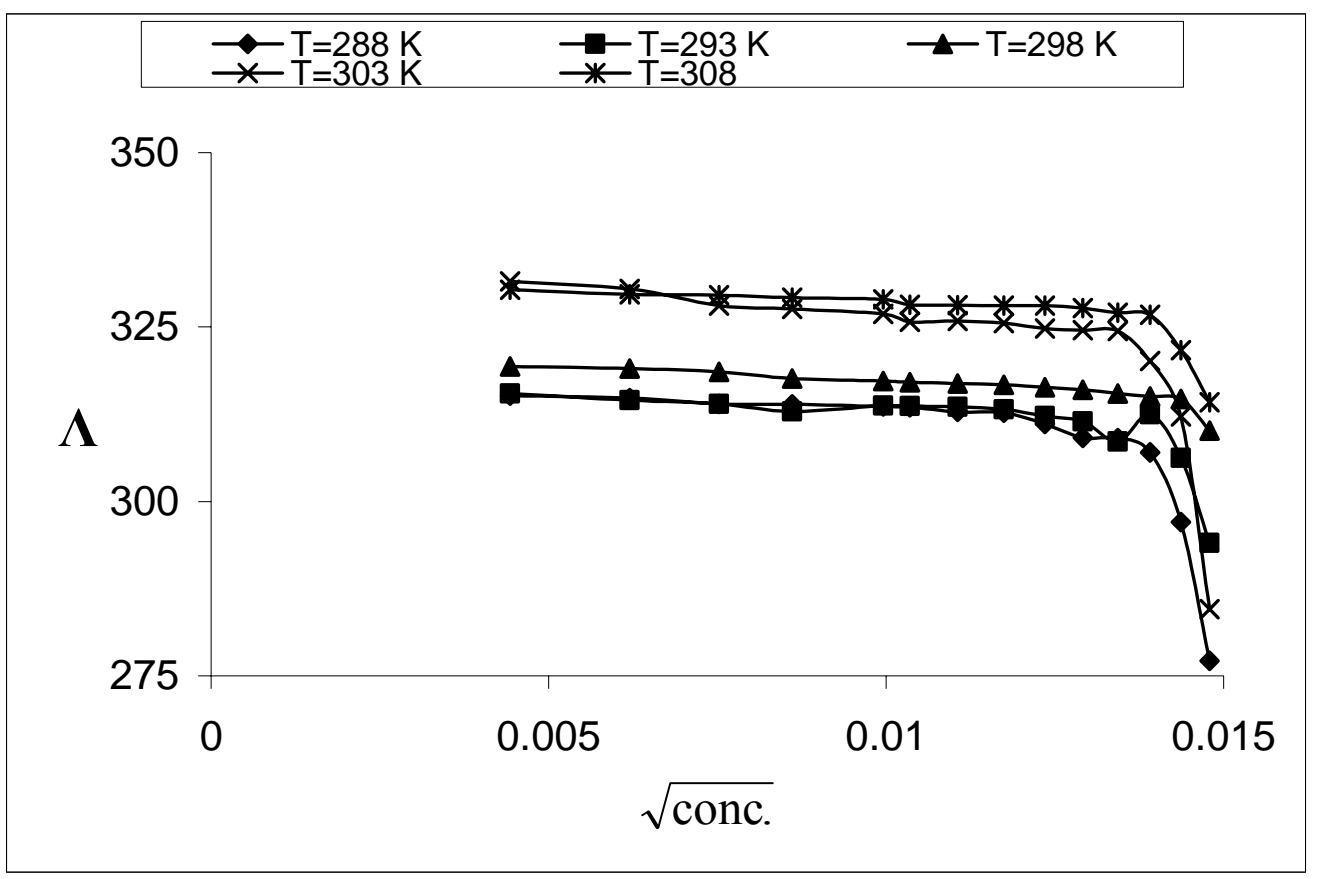

Fig (1-A) :The plot of equivalent conductivities $\left(\Omega^{-1} \cdot \mathrm{cm}^{2}\right.$.equiv $\left.{ }^{-1}\right)$ against square root of concentration (mole. $\mathrm{L}^{-1}$ ) for $\left[\mathrm{Fe}(\mathrm{phen})\left(\mathrm{H}_{2} \mathrm{O}\right)_{4}\right] \mathrm{Cl}_{2}$ in $90 \%$ methanol-water mixtures at different temperatures.

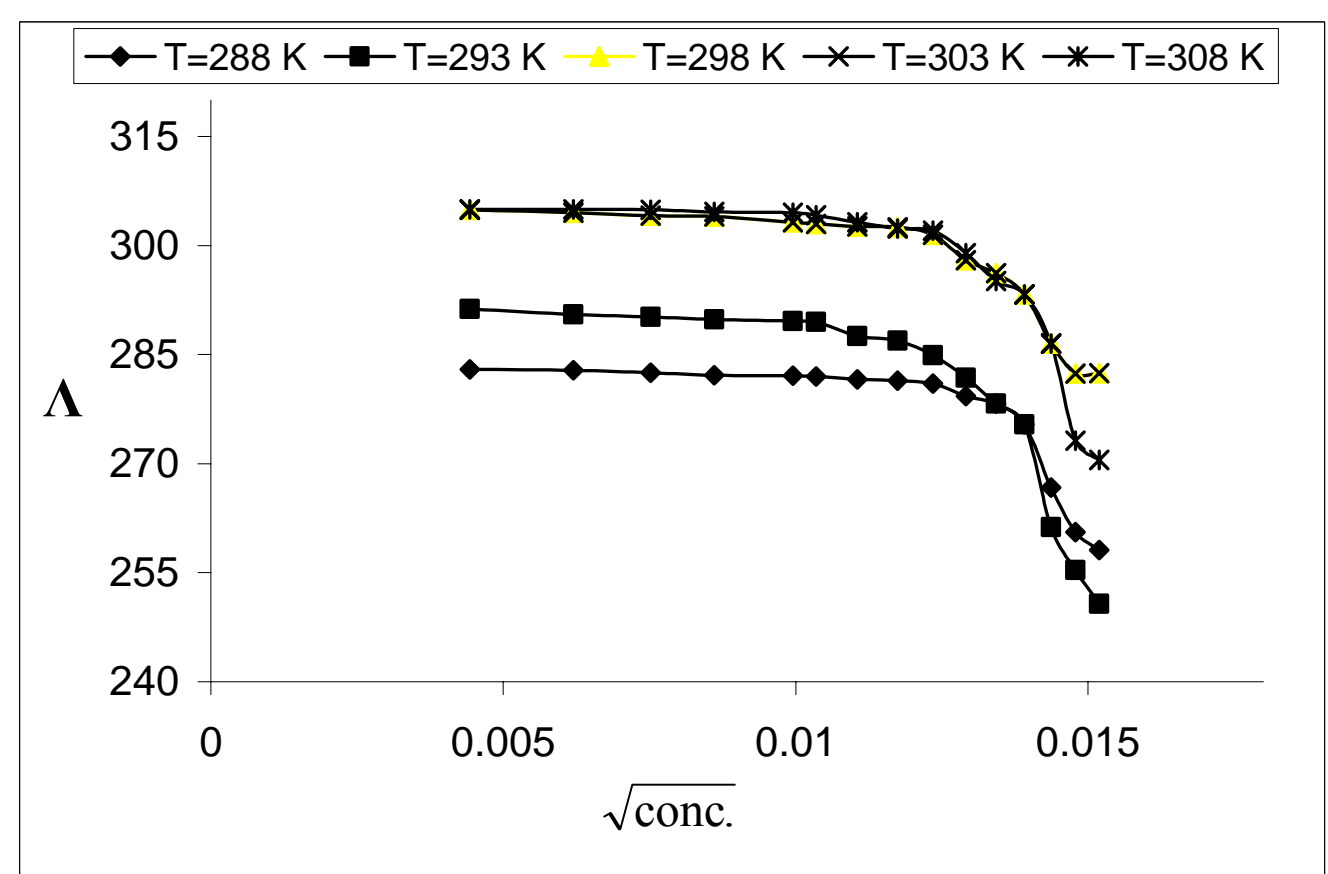

Fig (1-B) :The plot of equivalent conductivities $\left(\Omega^{-1} \cdot \mathrm{cm}^{2}\right.$.equiv $\left.{ }^{-1}\right)$ against square root of concentration $\left(\right.$ mole. $\left.\mathrm{L}^{-1}\right)$ for $\left[\mathrm{Fe}(\mathrm{phen})\left(\mathrm{H}_{2} \mathrm{O}\right)_{4}\right] \mathrm{Cl}_{2}$ in $80 \%$ methanol-water mixtures at different temperatures. 


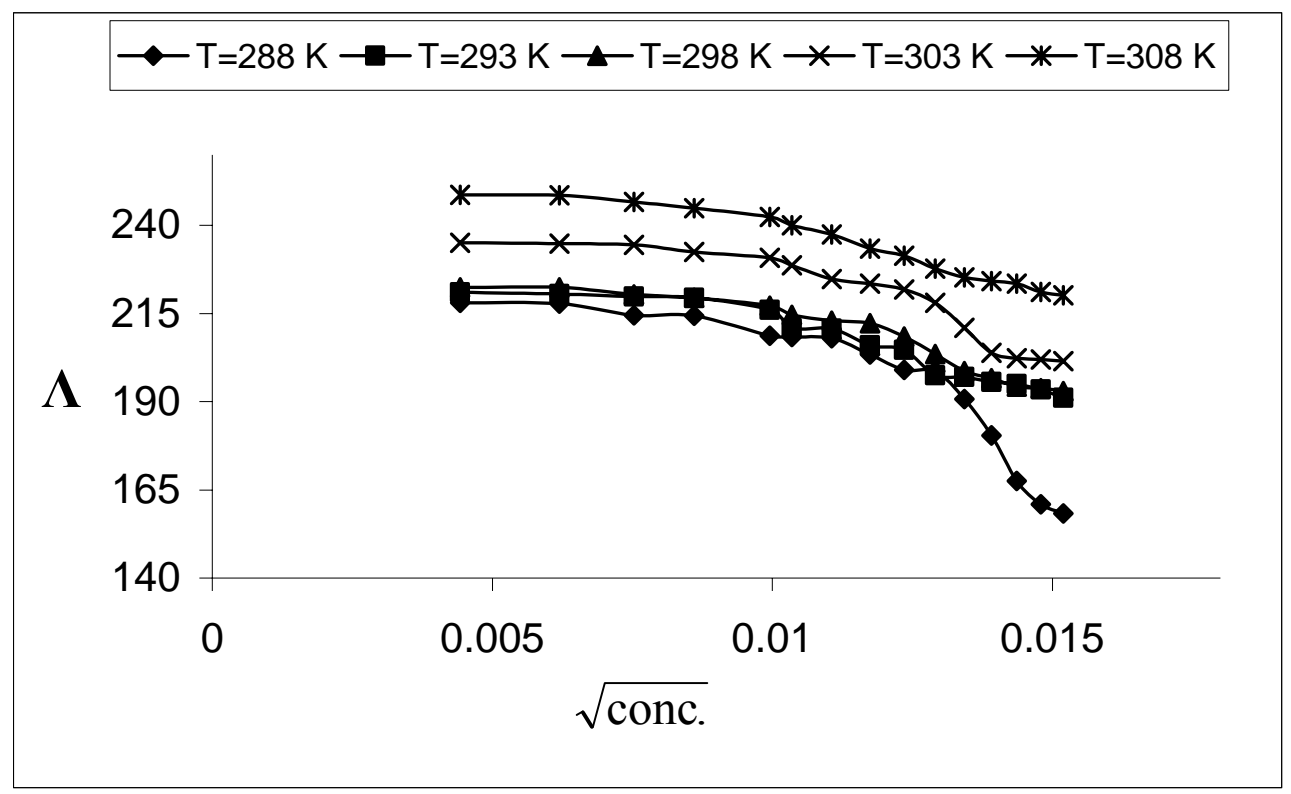

Fig (1-C) :The plot of equivalent conductivities $\left(\Omega^{-1} \cdot \mathrm{cm}^{2}\right.$.equiv $\left.{ }^{-1}\right)$ against square root of concentration (mole. $\left.\mathrm{L}^{-1}\right)$ for $\left[\mathrm{Fe}(\mathrm{phen})\left(\mathrm{H}_{2} \mathrm{O}\right)_{4}\right] \mathrm{Cl}_{2}$ in $70 \%$ methanol-water mixtures at different temperatures.

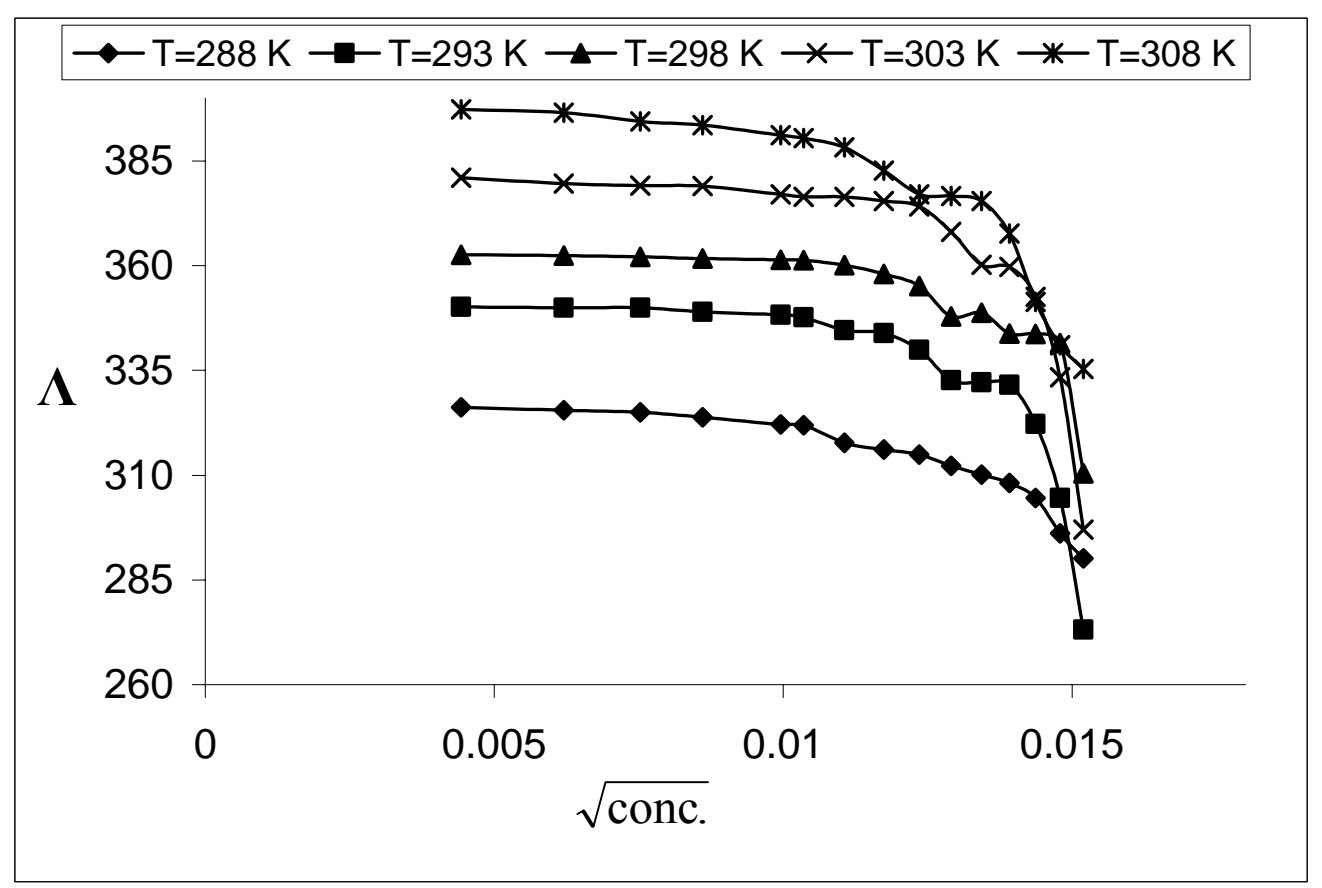

Fig (1-D) :The plot of equivalent conductivities $\left(\Omega^{-1} \cdot \mathrm{cm}^{2}\right.$.equiv $\left.{ }^{-1}\right)$ against square root of concentration $\left(\right.$ mole. $\left.\mathrm{L}^{-1}\right)$ for $\left[\mathrm{Fe}(\mathrm{phen})\left(\mathrm{H}_{2} \mathrm{O}\right)_{4}\right] \mathrm{Cl}_{2}$ in $50 \%$ methanol-water mixtures at different temperature. 
Table (1A): The equivalent conductivities $\left(\Omega^{-1} \cdot \mathrm{cm}^{2}\right.$.equiv $\left.{ }^{-1}\right)$ with molar concentration for $\left[\mathrm{Fe}(1,10-\mathrm{Phen})\left(\mathrm{H}_{2} \mathrm{O}\right)_{4}\right] \mathrm{Cl}_{2}$ in methanol water mixtures at different temperatures $(\mathrm{K})(\mathbf{9 0} \%)$

\begin{tabular}{|c|c|c|c|c|c|}
\hline conc. $\times 10^{-5}$ & $\mathrm{~T}=288 \mathrm{~K}$ & $\mathrm{~T}=293 \mathrm{~K}$ & $\mathrm{~T}=298 \mathrm{~K}$ & $\mathrm{~T}=303 \mathrm{~K}$ & $\mathrm{~T}=308 \mathrm{~K}$ \\
\hline 1.960 & 315.179 & 315.455 & 319.33 & 331.526 & 330.35 \\
\hline 3.846 & 314.822 & 314.526 & 319.029 & 330.468 & 329.688 \\
\hline 5.660 & 313.986 & 313.955 & 318.573 & 328.079 & 329.541 \\
\hline 7.407 & 313.878 & 312.88 & 317.616 & 327.607 & 329.175 \\
\hline 9.909 & 313.614 & 313.728 & 317.262 & 326.895 & 328.947 \\
\hline 10.714 & 313.506 & 313.656 & 317.072 & 325.756 & 328.162 \\
\hline 12.228 & 312.836 & 313.562 & 316.882 & 325.8283 & 328.102 \\
\hline 13.793 & 312.702 & 313.196 & 316.723 & 325.5736 & 328.073 \\
\hline 15.254 & 311.07 & 312.246 & 316.333 & 324.786 & 328.07 \\
\hline 16.666 & 309.111 & 311.439 & 316.008 & 324.52 & 327.712 \\
\hline 18.032 & 309.092 & 308.56 & 315.455 & 324.4013 & 327.028 \\
\hline 19.354 & 307.03 & 312.484 & 315.067 & 320.112 & 326.756 \\
\hline 20.634 & 297.065 & 306.261 & 314.676 & 312.17 & 321.651 \\
\hline 21.875 & 277.134 & 294.044 & 310.156 & 284.544 & 314.184 \\
\hline 23.076 & 194.769 & 296.742 & 302.328 & 215.118 & 299.754 \\
\hline
\end{tabular}

Table (1B): The equivalent conductivities $\left(\Omega^{-1} \cdot \mathrm{cm}^{2}\right.$.equiv $\left.{ }^{-1}\right)$ with molar concentration for $\left[\mathrm{Fe}(1,10-\mathrm{Phen})\left(\mathrm{H}_{2} \mathrm{O}\right)_{4}\right] \mathrm{Cl}_{2}$ in methanol water mixtures at different temperatures $(\mathrm{K})(80 \%)$

\begin{tabular}{|c|c|c|c|c|c|}
\hline conc. $\times 10^{-5}$ & $\mathrm{~T}=288 \mathrm{~K}$ & $\mathrm{~T}=293 \mathrm{~K}$ & $\mathrm{~T}=298 \mathrm{~K}$ & $\mathrm{~T}=303 \mathrm{~K}$ & $\mathrm{~T}=308 \mathrm{~K}$ \\
\hline 1.960 & 282.941 & 291.278 & 304.912 & 304.980 & 303.654 \\
\hline 3.846 & 282.846 & 290.496 & 304.493 & 304.950 & 303.552 \\
\hline 5.660 & 282.472 & 290.158 & 304.096 & 304.912 & 302.022 \\
\hline 7.407 & 282.132 & 289.850 & 304.018 & 304.606 & 299.221 \\
\hline 9.909 & 282.102 & 289.605 & 303.195 & 304.493 & 298.044 \\
\hline 10.714 & 281.996 & 289.476 & 302.940 & 304.164 & 297.344 \\
\hline 12.228 & 281.563 & 287.526 & 302.615 & 303.195 & 297.279 \\
\hline 13.793 & 281.404 & 286.926 & 302.498 & 302.328 & 296.888 \\
\hline 15.254 & 281.016 & 284.886 & 301.497 & 302.049 & 296.072 \\
\hline 16.666 & 279.256 & 281.792 & 297.976 & 298.928 & 295.647 \\
\hline 18.032 & 278.256 & 278.256 & 296.208 & 295.088 & 293.694 \\
\hline 19.354 & 275.406 & 275.400 & 293.301 & 293.301 & 291.924 \\
\hline 20.634 & 266.696 & 261.290 & 286.518 & 286.518 & 284.716 \\
\hline 21.875 & 260.563 & 255.350 & 282.357 & 273.156 & 270.504 \\
\hline 23.076 & 258.140 & 250.743 & 282.446 & 270.500 & 265.873 \\
\hline
\end{tabular}


Table (1C): The equivalent conductivities $\left(\Omega^{-1} \cdot \mathrm{cm}^{2}\right.$.equiv $\left.{ }^{-1}\right)$ with molar concentration for $\left[\mathrm{Fe}(1,10-\mathrm{Phen})\left(\mathrm{H}_{2} \mathrm{O}\right)_{4}\right] \mathrm{Cl}_{2}$ in methanol water mixtures at different temperatures $(\mathrm{K})(\mathbf{7 0 \%})$

\begin{tabular}{|c|c|c|c|c|c|}
\hline conc. $\times 10^{-5}$ & $\mathrm{~T}=288 \mathrm{~K}$ & $\mathrm{~T}=293 \mathrm{~K}$ & $\mathrm{~T}=298 \mathrm{~K}$ & $\mathrm{~T}=303 \mathrm{~K}$ & $\mathrm{~T}=308 \mathrm{~K}$ \\
\hline 1.960 & 217.989 & 221.019 & 222.438 & 235.008 & 248.636 \\
\hline 3.846 & 217.755 & 220.461 & 222.418 & 234.796 & 248.530 \\
\hline 5.660 & 214.489 & 219.759 & 220.386 & 234.515 & 246.636 \\
\hline 7.407 & 214.376 & 219.466 & 219.466 & 232.476 & 244.920 \\
\hline 9.909 & 208.692 & 216.036 & 217.260 & 230.742 & 242.352 \\
\hline 10.714 & 208.325 & 210.795 & 214.640 & 228.684 & 240.051 \\
\hline 12.228 & 207.955 & 210.757 & 212.899 & 224.808 & 237.379 \\
\hline 13.793 & 203.362 & 205.981 & 212.236 & 223.418 & 233.390 \\
\hline 15.254 & 198.968 & 204.680 & 208.437 & 221.762 & 231.336 \\
\hline 16.666 & 198.605 & 197.472 & 203.473 & 218.008 & 227.766 \\
\hline 18.032 & 190.740 & 196.940 & 198.594 & 210.936 & 225.230 \\
\hline 19.354 & 180.387 & 195.550 & 196.641 & 203.796 & 224.150 \\
\hline 20.634 & 167.586 & 194.940 & 194.320 & 202.320 & 223.500 \\
\hline 21.875 & 160.930 & 193.462 & 193.750 & 201.967 & 221.150 \\
\hline 23.076 & 158.356 & 191.116 & 192.911 & 201.532 & 220.130 \\
\hline
\end{tabular}

Table (1D): The equivalent conductivities $\left(\Omega^{-1} \cdot \mathrm{cm}^{2}\right.$.equiv $\left.{ }^{-1}\right)$ with molar concentration for $\left[\mathrm{Fe}(1,10-\mathrm{Phen})\left(\mathrm{H}_{2} \mathrm{O}\right)_{4}\right] \mathrm{Cl}_{2}$ in methanol water mixtures at different temperatures $(\mathrm{K})(\mathbf{5 0 \%})$

\begin{tabular}{|c|c|c|c|c|c|}
\hline conc. $\times 10^{-5}$ & $\mathrm{~T}=288 \mathrm{~K}$ & $\mathrm{~T}=293 \mathrm{~K}$ & $\mathrm{~T}=298 \mathrm{~K}$ & $\mathrm{~T}=303 \mathrm{~K}$ & $\mathrm{~T}=308 \mathrm{~K}$ \\
\hline 1.960 & 326.2 & 350.18 & 362.572 & 381.021 & 397.358 \\
\hline 3.846 & 325.5 & 349.969 & 362.417 & 379628 & 396.477 \\
\hline 5.660 & 325 & 349.928 & 362.049 & 379.09 & 394.434 \\
\hline 7.407 & 323.8 & 348.997 & 361.692 & 378.976 & 393.516 \\
\hline 9.909 & 322.1 & 348.228 & 361.371 & 376.992 & 391.17 \\
\hline 10.714 & 321.9 & 347.706 & 361.338 & 376.459 & 390.458 \\
\hline 12.228 & 317.7 & 344.607 & 360.136 & 376.405 & 388.215 \\
\hline 13.793 & 316.1 & 343.856 & 357.976 & 375.418 & 382.704 \\
\hline 15.254 & 314.9 & 339.864 & 355.096 & 374.136 & 376.992 \\
\hline 16.666 & 312.2 & 332.66 & 347.82 & 368.016 & 376.571 \\
\hline 18.032 & 310.1 & 332.112 & 348.796 & 360.192 & 375.43 \\
\hline 19.354 & 308.2 & 331.551 & 343.796 & 359.741 & 367.659 \\
\hline 20.634 & 304.6 & 322.218 & 343.716 & 352.512 & 351.39 \\
\hline 21.875 & 296.1 & 304.538 & 341.496 & 333.37 & 340.986 \\
\hline 23.076 & 290.1 & 273.156 & 310.45 & 297.024 & 335.282 \\
\hline
\end{tabular}


Table (2) show the results of analysis of the complex $[\mathrm{Fe}(1,10-$ Phen) $\left.\left(\mathrm{H}_{2} \mathrm{O}\right)_{4}\right] \mathrm{Cl}_{2}$ in different percentages of methanol-water $(90 \%-50 \%)$ at different temperatures by using Lee-Wheaton equation for unsymmetrical electrolytes $(2: 1)$ which indicates the values of $\left(\mathrm{K}_{\mathrm{A}}\right.$, $\lambda_{\mathrm{M}^{2+}}, \lambda_{\mathrm{MX}^{+}}, \mathrm{R}$ and $\left.\sigma \Lambda\right)$.

Table (2): The results of analysis of $\left[\mathrm{Fe}(1,10-\mathrm{Phen})\left(\mathrm{H}_{2} \mathrm{O}\right)_{4}\right] \mathrm{Cl}_{2}$ in different percentages and temperatures of methanol water by $\mathrm{L}-\mathrm{W}$ equation

\begin{tabular}{|c|c|c|c|c|c|}
\hline Temp. & $\mathrm{K}_{\mathrm{A}}$ & $\lambda_{\mathrm{M}^{2+}}$ & $\lambda_{\mathrm{MX}^{+}}$ & $\mathrm{RA}^{\mathrm{o}}$ & $\sigma \Lambda$ \\
\hline \multicolumn{6}{|c|}{$\% 90$ methanol } \\
\hline 288.15 & 180 & 277 & 1.0 & 50 & 0.020 \\
\hline 293.15 & 165 & 280 & 1.0 & 48 & 0.080 \\
\hline 298.15 & 130 & 284 & 1.0 & 45 & 0.025 \\
\hline 303.15 & 105 & 287 & 1.0 & 43 & 0.021 \\
\hline 306.15 & 73 & 292 & 1.0 & 40 & 0.053 \\
\hline \multicolumn{6}{|c|}{ \%80 methanol } \\
\hline 288.15 & 590 & 260 & 1.0 & 70 & 0.083 \\
\hline 293.15 & 575 & 267 & 1.0 & 67 & 0.083 \\
\hline 298.15 & 563 & 272 & 1.0 & 65 & 0.098 \\
\hline 303.15 & 557 & 275 & 1.0 & 62 & 0.090 \\
\hline 306.15 & 540 & 278 & 1.0 & 60 & 0.080 \\
\hline \multicolumn{6}{|c|}{$\% 70$ methanol } \\
\hline 288.15 & 670 & 170 & 1.0 & 78 & 0.010 \\
\hline 293.15 & 630 & 180 & 1.0 & 76 & 0.029 \\
\hline 298.15 & 620 & 190 & 1.0 & 73 & 0.036 \\
\hline 303.15 & 600 & 200 & 1.0 & 71 & 0.039 \\
\hline 306.15 & 580 & 210 & 1.0 & 70 & 0.039 \\
\hline \multicolumn{6}{|c|}{$\% 50$ methanol } \\
\hline 288.15 & 595 & 300 & 1.0 & 71 & 0.070 \\
\hline 293.15 & 570 & 320 & 1.0 & 69 & 0.019 \\
\hline 298.15 & 565 & 335 & 1.0 & 68 & 0.016 \\
\hline 303.15 & 530 & 342 & 1.0 & 66 & 0.013 \\
\hline 306.15 & 500 & 350 & 1.0 & 65 & 0.064 \\
\hline
\end{tabular}

From Table (2) the values of $\mathrm{K}_{\mathrm{A}}$ (association constant) decrease with increasing temperatures at each percentage because of breaking of $\mathrm{H}$ bonds formed at low temperature and this will lead to increasing of $\lambda_{\mathrm{M}^{2+}}$ as shown in Table (2) and $\mathrm{K}_{\mathrm{A}}$ is also increase as methanol percentage decrease because of increasing $\mathrm{H}$-bonding due to increasing water percentage and increasing viscosity which play an important role. Similar observations have also been noted for some electrolytes in other mixed solvents ${ }^{(14)}$, and this may be attributed to the selective solvation of ions besides the solvodynamic viscous force ${ }^{(15)}$. 
$\lambda_{\mathrm{MX}^{+}}$is almost constant and low value due to the formation of larger ion than $\lambda_{\mathrm{M}^{2+}}$ and more stable than the other ions $\left(\mathrm{M}^{2+}, \mathrm{X}^{-}\right)$.

The values of $\mathrm{R}$ (distance parameter) are high because of the isolated cation which tend to surrounded by extensive solvent shell which gives rise to are pulsive force between the ions which they come into close proximately and because of ion-dipol-ion forces will be significant to form solvent separated ion pair ${ }^{(16)}$. The small values of $(\sigma \Lambda)$ give an indication of good best fit value (less than 0.1 ).

Thermodynamic parameters from the association reaction are evaluated by the following equations:

$\ln \mathrm{K}_{\mathrm{A}}=-\Delta \mathrm{H} / \mathrm{RT}+\mathrm{C}$

$\Delta \mathrm{G}=-\mathrm{RT} \ln \mathrm{K}_{\mathrm{A}}$

$\Delta \mathrm{S}=(\Delta \mathrm{H}-\Delta \mathrm{G}) / \mathrm{T}$

The enthalpy evaluated from Fig. (2) by plotting $\operatorname{lnKa}$ against $1 / \mathrm{T}$ from the equation:

$\ln \mathrm{Ka}=-\frac{\Delta \mathrm{H}}{\mathrm{RT}}+\mathrm{c}$

and $(\Delta \mathrm{H})$ of ion association reaction according to the activated complex theory is a result of the energies being expended for the distruction of solvent-solvent bonds, and the formation of solvent ion bonds. As can be noticed from Table (3), $\Delta \mathrm{H}$ decrease with decreasing methanol percentage due to the broken of ion-ion bond in solution as a result of increasing dielectric constant of the solvent by increasing water percentage ${ }^{(17)}$. The entropy is positive as water percent age increase of the complex and this may be recognized as a structure-maker in these media. Finally, the values of $\Delta \mathrm{G}$ are negative which indicate the reaction is spontaneous.

The value of Walden product $\left(\Lambda_{0} \eta\right)$ would be constant only if the effective radius of the ion remains the same in the different media. Since most ions are solvated in solution to different extent, the dimensions of the moving will undoubtedly vary to some extent and exact constancy of the conductance viscosity product is not to be expected ${ }^{(18)}$. This is the case in the behaviour of the present system as indicate in Fig. (3) where the cations are expected to suffer various degree of solvation with increasing amount of methanol in the methanol-water mixtures. The major deviation in the Walden product is due to the variation of the electrochemical equilibrium between ions and the solvent molecules with the composition of the mixed polar solvent. 


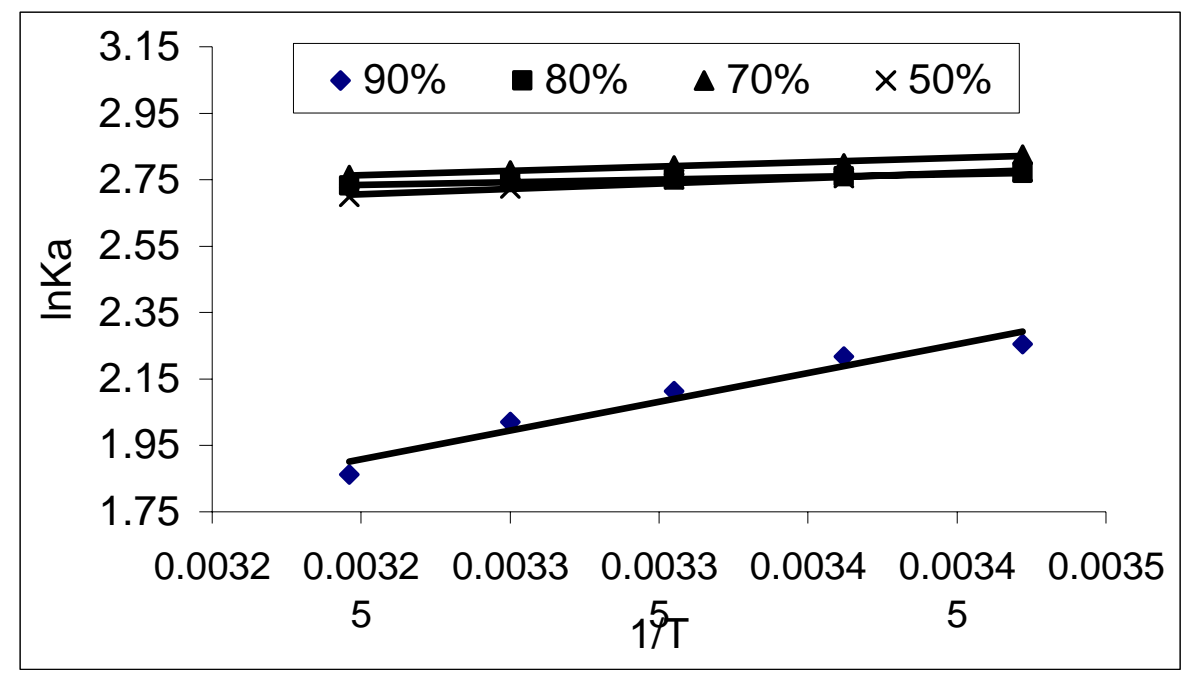

Fig (2): Plot of InKa against 1/T for the complexes at different solvent composition

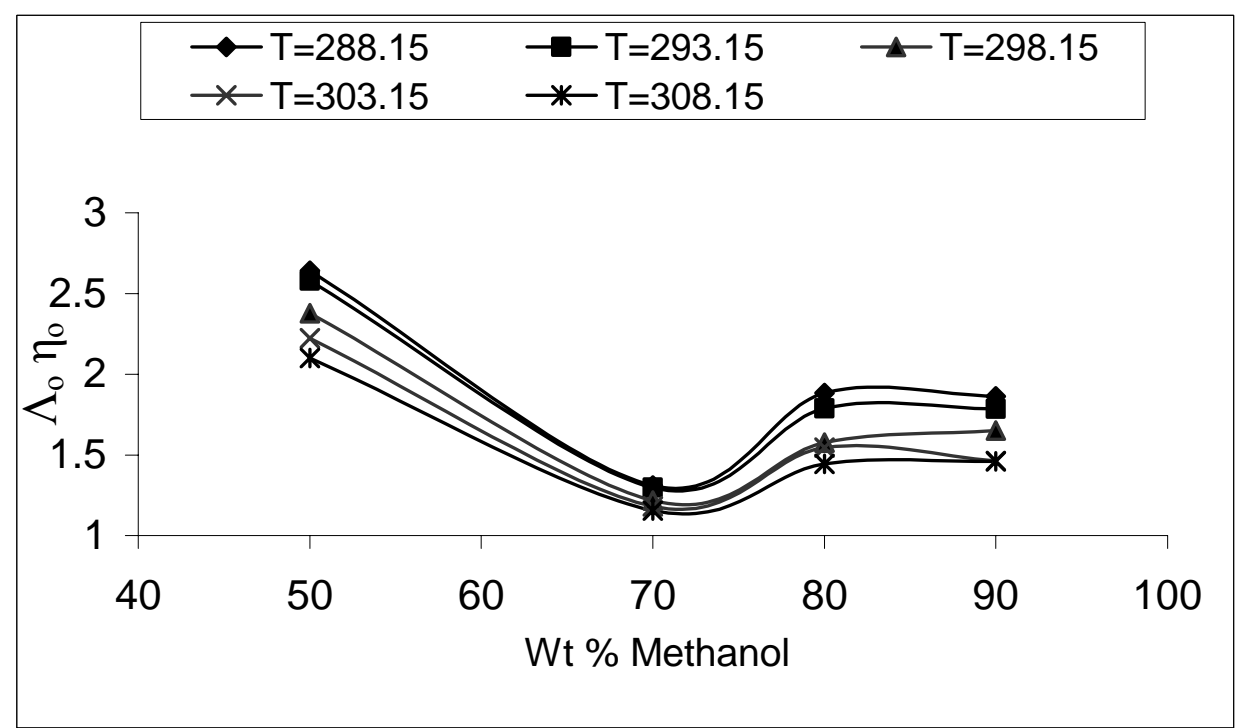

Fig (3) : Walden products $\left(\Lambda_{0} \eta_{0}\right)$ for the complex in methanol-water mixture plotted versus the composition of the mixture at different temperature 
Table (3): Thermodynamic parameters $(\Delta H, \Delta G, \Delta S)$ of the complex in different solvent composition from the association constant $\left(K_{\mathrm{A}}\right)$

\begin{tabular}{|c|c|c|c|}
\hline Temp. & $\Delta \mathrm{G} \mathrm{Kcal} / \mathrm{mole}$ & $\Delta \mathrm{S}$ cal/deg.mole & $\Delta \mathrm{H} \mathrm{Kcal} / \mathrm{mole}$ \\
\hline \multicolumn{4}{|c|}{$\% 90$ methanol } \\
\hline 288.15 & -2.963 & -17.877 & \multirow{5}{*}{-7.884} \\
\hline 293.15 & -2.964 & -16.783 & \\
\hline 298.15 & -2.873 & -16.856 & \\
\hline 303.15 & -2.793 & -16.793 & \\
\hline 306.15 & -2.575 & -17.228 & \\
\hline \multicolumn{4}{|c|}{$\% 80$ methanol } \\
\hline 288.15 & -3.640 & 7.083 & \multirow{5}{*}{-0.729} \\
\hline 293.15 & -3.688 & 6.924 & \\
\hline 298.15 & -3.739 & 6.778 & \\
\hline 303.15 & -3.795 & 6.540 & \\
\hline 306.15 & -3.839 & 6.500 & \\
\hline \multicolumn{4}{|c|}{$\% 70$ methanol } \\
\hline 288.15 & -3.713 & 5.694 & \multirow{5}{*}{-1.185} \\
\hline 293.15 & -3.741 & 5.505 & \\
\hline 298.15 & -3.796 & 5.389 & \\
\hline 303.15 & -3.840 & 5.254 & \\
\hline 306.15 & -3.882 & 5.120 & \\
\hline \multicolumn{4}{|c|}{$\% 50$ methanol } \\
\hline 288.15 & -3.645 & 4.532 & \multirow{5}{*}{-1.468} \\
\hline 293.15 & -3.683 & 4.390 & \\
\hline 298.15 & -3.741 & 4.306 & \\
\hline 303.15 & -3.765 & 4.143 & \\
\hline 306.15 & -3.730 & 3.991 & \\
\hline
\end{tabular}

\section{REFERENCES}

1. Y. Fukuda and K. Sone, Bull. Chem. Soc., Jpn., 45, 465-469, (1972).

2. M. Van Meter and H.M. Newmann, J. Amer. Chem. Soc., 98, 1382-1388, (1976).

3. E. Iwamoto, M. Yamamoto and Y. Yamamoto, Inorg. Nucl. Chem. Lett., 13, 389-402, (1997).

4. T. Tamingo, J. Phys. Chem., 79, 16-20, 1644-1670, (1975).

5. S. Newmann, E. Blinn and L. Carison, J. Phys. Chem., 83, 676680, (1979).

6. S. Daygupta, E. Vallazza and R. Schimd, J. Chem. Soc. Dalton Trans., 15, 2387-2391, (1993). 
7. B. A. Akrawi and Y. O. Al-Allaf, Raf. J. Sci., Chemistry Special Issue, 13, 76-84, (2002).

8. N. G. Tsierkezos and L. E. Molinou, J. Chem. Eng. Data, 45 (5), 819-822, (2000).

9. W. U. Malik, R. Benbi and V. K. Bhardwaj, J. Indian Chem. Soc., 1, VII (1980), 35-38.

10. W. L. F. Armarego, D. D. Perrin, "Purification of Laboratory Chemicals", $4^{\text {th }}$ ed., (1998), pp. 50-51.

11. G. Jones and B. C. Bradshow, J. Amer. Chem. Soc., 55, 1780, (1933).

12. W. H. Lee and R. J. Wheaton, J. Chem. Soc. Faraday Trans. II, 74, 743, (1978).

13. W. H. Lee and R. J. Wheaton, J. Chem. Soc. Faraday Trans. II, 75, 1128, (1979).

14. S. P. Jouher, P. S. Guraga and S. P. Narula, J. Indian Chem., 27, 629-631, (1988).

15. H. Doe, H. Che and H. Matoda, Bull. Chem. Soc. Jpn., 63, 2785, (1990).

16. H. A. Naema, Iraqi J. Chem., 28, 1, 97-105, (2002).

17. I. Tominic, R. Tomas M. Vissic and V. Sokol, Croat. Chem. Acta., 77 (3), 537-543 (2004).

18. P. Hemmes, J. Phys. Chem., 78(9), 97-909, (1974). 